\title{
Pengaruh Gaya Kepemimpinan Kepala Sekolah Terhadap Kinerja Guru
}

\section{The Influence of Headmaster Leadership Style on Teacher Performance}

\author{
Sukmawati, ${ }^{1}$ Jamaluddin $^{1}$, Risma Niswaty ${ }^{1}$, Asmanurhidayani ${ }^{2}$ \\ ${ }^{1}$ Universitas Negeri Makassar \\ ${ }^{2}$ Universitas Puangrimaggalatung, Sengkang
}

\begin{abstract}
ABSTRAK
Kepala sekolah sebagai pemimpin pada suatu sekolah memiliki peran yang sangat penting. Penelitian ini bertujuan untuk mengetahui pengaruh gaya kepemimpinan kepala sekolah terhadap kinerja guru di SMK Negeri 1 Gowa. Penelitian ini merupakan penelitian kuantitatif. Responden adalah semua guru SMK Negeri 1 Gowa. Teknik pengumpulan data yang digunakan melalui observasi, kuesioner (angket), wawancara dan dokumentasi. Data yang telah diperoleh dari hasil penelitian diolah dengan menggunakan teknik analisa data yang terdiri atas teknik analisis deskriptif dan analisis statistik inferensial. Hasil penelitian menunjukkan bahwa pengaruh gaya kepemimpinan kepala sekolah SMK Negeri 1 Gowa dalam kategori sangat baik dengan tingkat persentase 84,03 persen, dan untuk kinerja guru SMK Negeri 1 Gowa termasuk dalam ketegori sangat baik dengan tingkat persentase 84,49 persen. Hal ini dapat dibuktikan dengan hasil analisis korelasi produk momen sebesar 0,280 yang berarti tingkat hubungan dalam kategori rendah. Dapat disimpulkan bahwa ada Pengaruh Positif dan Signifikan pengaruh gaya kepemimpinan kepala sekolah terhadap kinerja Guru di SMK Negeri 1 Gowa, dilihat dari beberapa indikator variabel kepemimpinan, yaitu gaya directing gaya coaching, dan gaya supporting. Variabel kinerja guru, yaitu sebagai perancang pembelajaran, sebagai pengarah pembelajaran, sebagai pengelola pembelajaran, sebagai konselor, sebagai evaluator, dan sebagai pelaksana kurikulum.
\end{abstract}

Kata kunci: Kepemimpinan, kepala sekolah, kinerja, guru

\begin{abstract}
The headmaster as a leader in a school has a very important role. This study aims to determine the effect of the headmaster leadership style on teacher performance at State Vocational School 1 Gowa. This research is quantitative research. Respondents were all teachers of State Vocational School 1 Gowa. Data collection techniques used through observation, questionnaires (questionnaires), interviews and documentation. Data obtained from the results of the study were processed using data analysis techniques consisting of descriptive analysis techniques and inferential statistical analysis. The results showed that the influence of the leadership style of the principal of the State Vocational School 1 Gowa was in a very good category with a percentage rate of 84.03 percent, and for the teacher performance of the State Vocational School 1 Gowa included in the very good category with a percentage rate of 84.49 percent. This can be proven by the results of the moment product correlation analysis of 0.280, which means the level of relations in the low category. It can be concluded that there is a Positive and Significant Influence of the influence of headmaster leadership style on the performance of teachers at State Vocational School 1 Gowa, seen from several indicators of leadership variables, namely directing style coaching style, and supporting style. Teacher performance variables, namely as learning designers, as instructors of learning, as managers of learning, as counselors, as evaluators, and as implementers of the curriculum.
\end{abstract}

Keywords: Leadership, headmaster, performance, teacher 


\section{$92 \mid$ Jurnal Office: Jurnal Pemikiran Ilmiah dan Pendidikan Administrasi Perkantoran Vol. 4, No. 2, Juli-Desember 2018, Hal 91-102}

\section{PENDAHULUAN}

Sekolah adalah lembaga yang bersifat kompleks dan unik (Drake, 2008; Haworth, 1983; Thapa, Cohen, Guffey, \& Higgins-D’Alessandro, 2013). Bersifat kompleks karena sekolah sebagai organisasi didalamnya terdapat sebagai dimensi yang satu sama lain saling berkaitan dan saling menentukan. Sedang sifat unik, menunjukan bahwa sekolah sebagai organisasi memiliki ciri-ciri yang menempatkan sekolah memiliki karakter tersendiri, dimana terjadi proses belajar mengajar, tempat terselenggaranya pembudayaan kehidupan umat manusia. Kepala sekolah merupakan jabatan yang penting dalam dunia pendidikan karena harus mengetahui keadaan sekolah, mengenal karakteristik setiap bawahannya, serta mampu adil dan tidak berpihak kepada siapapun dalam proses pengambilan keputusan. (Ismayani, Niswaty, \& Darwis, 2015; Nasrullah, Rumingan, Nasaruddin, \& Niswaty, 2017; Sahandri \& Hamzah, 2009; Şahenk, 2010). Kepala sekolah yang berhasil apabila mereka memahami keberadaan sekolah sebagai organisasi yang kompleks dan unik, serta mampu melaksanakan peranan kepala sekolah sebagai seseorang yang diberi tanggung jawab untuk memimpin sekolah. Kepala sekolah sebagai pemimpin pada suatu sekolah memiliki peran yang sangat penting dan menentukan kemajuan sekolah sehingga kepala sekolah harus menyelenggarakan pendidikan di sekolah secara profesional. Keberhasilan sekolah adalah keberhasilan kepala sekolah, beberapa di antara kepala sekolah dilukiskan sebagai orang yang memiliki harapan tinggi bagi para staf dan para siswa, kepala sekolah adalah mereka yang banyak mengetahui tugas-tugas mereka dan mereka yang menentukan irama bagi sekolah mereka.

Gaya kepemimpinan merupakan suatu cara yang digunakan pemimpin dalam berinteraksi dangan bawahannya (Chen \& Silverthorne, 2005; Davis, Buskist, \& Miller, 2012) Gaya kepemimpinan yang diaplikasikan seorang pemimpin tidak sertamerta langsung pada pencapaian tujuan organisasi, tetapi akan memberikan pengaruh atau akan membangkitkan motivasi kerja pegawai (Batista-Taran, Shuck, Gutierrez, \& Baralt, 2017; Elqadri, Priyono, Suci, \& Chandra, 2015; Pencheon, 2000). Kepemimpinan kepala sekolah merupakan motor penggerak, penentu arah kebijakan sekolah yang akan menentukan tujuan-tujuan sekolah. Kepala sekolah dituntut untuk mempunyai taktik yang tepat dan senantiasa meningkatkan efektifitas kinerjanya. Pola dan metode yang diterapkan kepala sekolah melalui gaya kepemimpinananya akan meningkatkan kinerja guru dalam mengajar. Kinerja mengajar Guru akan optimal, jika kepala sekolah dapat membimbing guru-guru secara baik sehingga para guru dapat melaksanakan tugas-tugasnya dengan penuh tanggung jawab, memperhatikan kepentingan dan kesejahteraan bawahannya sehingga tidak ada keluhan dalam menjalankan tugas dan kewajibannya sehari-hari, harus menunjukkan kewibawaanya sehari-hari, sehingga dapat diteladani dan dipatuhi oleh guru maupun siswa. Peningkatan kinerja Guru dapat dilakukan melalui layanan supervisi pembelajaran kepala sekolah, layanan supervisi itu bertujuan untuk meningkatkan profesionalisme, kinerja guru serta mutu proses dan hasil kegiatan pembelajaran. Peningkatan kinerja guru mutlak diperlukan (Dobson, 1985; Taylor \& Tyler, 2012). Keberhasilan sekolah sangat berpengaruh oleh keberhasilan kepala sekolah dalam mengelola 
tenaga pendidik yang berada di sekolah. Untuk itu pola dan metode yang diterapkan kepala sekolah melalui gaya kepemimpinannya akan meningkatkan kinerja para guru dalam mengajar. Keberhasilan dan kegagalan seseorang guru dalam menjalankan tugas yang dibebankan kepadanya sangat dipengaruhi kepemimpinan kepala sekolah. Jika kepala sekolah dapat membimbing guru-guru secara baik sehingga guru dapat melaksanakan tugas-tugasnya dengan penuh tanggungjawab, memperhatikan kepentingan dan kesejahteraan bawahannya sehingga tidak ada keluhan dalam menjalankan tugas dan kewajiban sehari-hari, harus menunjukkan kewibawaannya sehari-sehari, sehingga dapat diteladani dan dipatuhi oleh guru maupun siswa.

\section{METODE PENELITIAN}

Penelitian ini merupakan penelitian kuantitatif. Populasi dalam penelitian ini adalah jumlah seluruh guru di SMK Negeri 1 Gowa sebanyak 91 orang, karena jumlah responden kurang dari 100, olehnya itu penelitian ini merupakan penelitian populasi. Teknik pengumpulan data yang digunakan adalah observasi, angket, wawancara dan teknik dokumentasi. Teknik analisis data yang digunakan adalah analisis statistik deskriptif dan analisis statistic inferensial. Analisis statistik deskriptif bertujuan untuk mendeskripsikan kedua variabel dengan menggunakkan analisis distribusi frekuensi, rata-rata (mean), dan standar deviasi. Analisis statistic inferensial yang digunakan adalah uji normalitas data, analisis korelasi produk momen dan analisis regresi linear sederhana.

\section{HASIL PENELITIAN DAN PEMBAHASAN}

\section{Analisis Stataistik Deskriptif}

Variabel gaya kepemimpinan kepala sekolah terdiri atas 3 indikator yaitu : gaya directing (mengarahkan), gaya coaching (melatih), dan gaya supporting (mendukung). Untuk lebih jelasnya penyajian dan pengolahan data disajikan dalam tabel berikut:

Tabel 1.

Hasil Analisis Data Variabel Kepemimpinan Kepala Sekolah (X)

\begin{tabular}{clcccc}
\hline No. & \multicolumn{1}{c}{ Indikator } & n & $\mathbf{N}$ & $\mathbf{\%}$ & Kategori \\
\hline 1 & Gaya directing (mengarahkan) & 767 & 910 & 84,29 & Baik \\
2 & gaya coaching (melatih) & 1148 & 1365 & 84,10 & Baik \\
3 & gaya supporting (mendukung) & 1144 & 1365 & 83,81 & Baik \\
\hline Jumlah & 3059 & 3640 & 84,03 & Baik \\
\hline
\end{tabular}

Sumber : Hasil Olah Angket 2019

Gaya directing berada pada kategori baik dengan tingkat persentase sebesar 84,29 persen, hasil ini menunjukkan bahwa kepala sekolah memberikan pengarahan yang baik. Gaya coaching berada pada kategori baik dengan tingkat persentase 84,10 persen. Hasil persentase tersebut menunjukkan bahwa kepala sekolah memperhatikan proses belajar mengajar dan memberikan motivasi terhadap guru. Gaya supporting berada pada kategori baik dengan tingkat 
94| Jurnal Office: Jurnal Pemikiran Ilmiah dan Pendidikan Administrasi Perkantoran

Vol. 4, No. 2, Juli-Desember 2018, Hal 91-102

persentase 83,81 persen . hasil persentase tersebut menunjukkan bahwa kepala sekolah memperhatikan ketersediaan sarana pembelajaran. Berdasarkan hasil analisis tabel 1, variabel kepemimpinan Kepala sekolah (X) berada pada ketegori baik dengan tingkat presentase 84,03 persen. Hasil analisis ini didapat dari oleh angket yang telah diisi sebelumnya oleh responden. Adapun analisis rata-rata variabel kepemimpinan Kepala sekolah (X) dapat dilihat pada tabel 2.

Tabel 2.

Analisis Deskriptif Variabel Kepemimpinan Kepala Sekolah

\begin{tabular}{lll}
\hline \multicolumn{2}{c}{ Kepemimpinan Kepala Sekolah } \\
\hline $\mathrm{N}$ & Valid & 91 \\
& Missing & 0 \\
Mean & & 33.62 \\
Median & & 34.00 \\
Mode & 33 \\
Std. Deviation & & 1.555 \\
Minimum & & 28 \\
Maximum & & 37 \\
\hline
\end{tabular}

Sumber: Hasil Analisis Statistik Melalui Program SPSS.16

Berdasarkan hasil rata-rata (mean) dan standar deviasi pada variabel kepemimpinan kepala sekolah (X) menunjukkan bahwa nilai rata-rata yang diperoleh dari skor jawaban responden sebesar 33,62 dan apabila disesuaikan dengan standar pengukuran variabel, maka rata-rata 33,62 berada pada kategori cukup baik dengan standar deviasi 1,555. Hasil nilai ratarata (mean) dan standar deviasi pada tabel ditinjau dari indikator gaya directing (mengarahkan), gaya coaching (melatih), dan gaya supporting (mendukung).

Pada variabel kinerja guru terdapat 6 indikator yaitu: sebagai perancang pembelajaran, sebagai pengarah pembelajaran, sebagai pengelola pembelajaran, sebagai konselor, sebagai evaluator, dan sebagai pelaksana kurikulum. Untuk lebih jelasnya dapat dilihat pada tabel 3.

\section{Tabel 3.}

Hasil Analisis Data Per Indikator Variabel Kinerja Guru(Y)

\begin{tabular}{|c|c|c|c|c|c|}
\hline No & Indikator & $\mathrm{n}$ & $\mathbf{N}$ & $\%$ & Kategori \\
\hline 1 & $\begin{array}{l}\text { Sebagai perancang } \\
\text { pembelajaran }\end{array}$ & 1168 & 1365 & 85,57 & Sangat Baik \\
\hline 2 & Sebagai pengelola pembelajaran & 753 & 910 & 82,75 & Baik \\
\hline 3 & Sebagai pengarah pembelajaran & 754 & 910 & 82,86 & Baik \\
\hline 4 & Sebagai evaluator & 763 & 910 & 83,85 & Sangat Baik \\
\hline 5 & Sebagai konselor & 768 & 910 & 94,40 & Sangat Baik \\
\hline 6 & Sebagai pelakasana kurikulum & 792 & 910 & 87,03 & Sangat Baik \\
\hline \multicolumn{2}{|c|}{ Jumlah } & 4998 & 5915 & 84,49 & Sangat Baik \\
\hline
\end{tabular}


Sumber: Hasil Olah Data Angket 2019

Indikator guru sebagai perancang pembelajaran berada pada kategori sangat baik dengan tingkat persentase 85,57 persen. Hasil persentase tersebut menunjukkan bahwa Guru di SMK Negeri 1 Gowa mempersiapkan materi pembelajaran yang relevan dengan tujuan pembelajaran dan guru merancang metode pembelajaran sesuai dengan kondisi peserta didik. Indikator guru sebagai perancang pembelajaran berada pada kategori baik dengan tingkat persentase 82,75 persen. Hasil persentase tersebut menunjukkan bahwa guru di SMK Negeri 1 Gowa dapat mengendalikan pelaksanaan pengajaran hingga mencapai tujuan pembelajaran. Indikator guru sebagai pengarah pembelajaran berada pada kategori baik dengan tingkat persentase 82,86 persen. Hasil persentase tersebut menunjukkan bahwa guru di SMK Negeri 1 Gowa selalu memberikan motivasi dalam proses belajar mengajar dan memberikan arahan agar peserta didik dapat mencapai tujuan pembelajaran. Indikator guru sebagai evaluator berada pada kategori sangat baik dengan tingkat persentase 83,85 persen. Hasil persentase tersebut menunjukkan bahwa guru di SMK Negeri 1 Gowa memberikan umpan balik dalam proses pembelajaran dan memperhatikan hasil belajar peserta didik. Indikator guru sebagai konselor yang menjadi indikator kinerja guru berada pada kategori sangat baik dengan tingkat persentase 84,40 persen. Hasil persentase tersebut menunjukkan bahwa guru di SMK Negeri 1 Gowa mampu menjalin komunikasi yang baik terhadap sesama guru, kepala sekolah dan siswa. Indikator guru sebagai pelakasana kurikulum yang menjadi indikator kinerja guru berada pada kategori sangat baik dengan tingkat persentase 87,03 persen. Hasil persentase tersebut menunjukkan bahwa guru di SMK Negeri 1 Gowa menganalisis tujuan pembelajaran berdasarkan apa yang tertuang dalam kurikulum.

Berdasarkan hasil analisis tabel 3, variabel kinerja guru berada pada ketegori sangat baik dengan tingkat presentase 84,49 persen. Hasil analisis ini didapat dari oleh angket yang telah diisi sebelumnya oleh responden. Adapun analisis rata-rata variabel kinerja Guru (Y) dapat dilihat pada tabel 4 .

\section{Tabel 4.}

\section{Hasil Analisis Deskriptif Variabel Kepemimpinan Kepala Sekolah}

$\mathrm{N}$

Valid

91.00

Missing

0.00

Mean

54.92

Median

Mode

Std. Deviation

Minimum

Maximum

Sumber: Hasil Analisis Statistik Melalui Program SPSS.16 


\section{6| Jurnal Office: Jurnal Pemikiran Ilmiah dan Pendidikan Administrasi Perkantoran Vol. 4, No. 2, Juli-Desember 2018, Hal 91-102}

Berdasarkan hasil analisis rata - rata (mean) dan standar deviasi pada variabel kualitas pembelajaran (Y) pada tabel 4, menunjukkan bahwa nilai rata-rata yang diperoleh dari skor jawaban responden sebesar 54,92 yang berada pada kategori cukup baik dengan standar deviasi 2,125 .

\section{Uji Normalitas Data}

Sebelum melakukan analisis korelasi produk momen, terlebih dahulu dilakukan pengujian normalitas data sebagai persyaratan yang akan digunakan dalam pengujiian hipotesis. Pengujian persyaratan analisis untuk pengunaan statistik adalah data yang diperoleh sekurang-kurangnya berdistribusi normal. Uji normalitas data dimaksudkan untuk mengetahui kenormalan data mengenai gaya kepemipinan kepala sekolah dan kinerja guru di SMK Negeri 1 Gowa. Pengujian dilakukan dengan cara membandingkan harga Chi Kuadrat hitung dengan Chi Kuadrat Tabel. Bila harga Chi Kuadrat hitung lebih kecil atau sama dengan Chi Kuadrat Tabel $\left(\mathrm{X}_{\mathrm{h}}{ }_{\mathrm{h}} \leq \mathrm{X}_{\mathrm{t}}{ }_{\mathrm{t}}\right)$, maka distribusi data dinyatakan normal, jika terjadi sebaliknya maka data dikatakan tidak normal. Hasil normalitas data dapat dilihat pada tabel 7 berikut ini:

\section{Tabel 5.}

\section{Rangkuman Hasil Pengujian Normalitas Data dengan Sig.5\%.}

\begin{tabular}{lllll}
\hline Variabel & $\mathbf{X}^{2}{ }_{\text {hitung }}$ & $\mathbf{X}_{\text {tabel }}^{2}$ & DF & Keterangan \\
\hline $\begin{array}{l}\text { Kepemimpinan Kepala } \\
\text { Sekolah }\end{array}$ & 96,863 & 16,919 & 9 & Normal \\
Kinerja Guru & & & & \\
& 68,923 & 18,307 & 10 & Normal
\end{tabular}

Sumber: Hasil Analisis Statistik Melalui Program SPSS.16

Berdasarkan tabel 5 secara jelas dilihat kerja uji normalitas data, bahwa nilai chi kuadrat hitung variabel gaya kepemimpinan kepala sekolah sebesar 96,863 sama dengan chi kuadrat tabel 16,919 dengan df 9 sedangkan, variabel kinerja guru dengan nilai chi kuadrat hitung sebesar 68,923 sama dengan chi kuadrat tabel 18,307 dengan df sebesar 10. Dari pengujian statistik diatas, menunjukkan bahwa variabel gaya kepemimpinan kepala sekolah maupun kinerja Guru SMK Negeri 1 Gowa memenuhi kriteria data berdistribusi normal.

\section{Uji Korelasi Product Moment}

Uji korelasi produk moment dimaksudkan untuk mengetahui ada tidaknya hubungan antara gaya kepemimpinan kepala sekolah terhadap kinerja guru pada SMK Negeri 1 Gowa, adapun hasil analisis korelasi produk moment dapat dilihat pada tabel 6 . 


\section{Tabel 6.}

\section{Hasil Pengujian Korelasi Product Moment dengan Signifikan 5\%}

Sumber: Hasil Analisis Data Melalui Program SPSS 16.

\begin{tabular}{lllll}
\hline Model & $\mathrm{R}$ & R Square & Adjusted R Square & $\begin{array}{l}\text { Std. Error of the } \\
\text { Estimate }\end{array}$ \\
\hline 1 & $.280^{\mathrm{a}}$ & .078 & .068 & 2.051 \\
\hline
\end{tabular}

a. Predictors: (Constant), Kepemimpinan Kepala sekolah

Berdasarkan analisis korelasi hasil perhitungan korelasi produk momen, diperoleh hasil korelasi antara gaya kepemimpinan kepala sekolah (X) dan kinerja Guru (Y), yaitu $r_{\text {hitung }}=$ 0,280, jika diinterpretasikan berdasarkan pendapat Sugiyono maka, 0,280 berada pada rentang 0,20-0,399 yang memiliki tingkat hubungan yang rendah.

\section{Analisis Regresi Linear Sederhana}

Tujuan dari penggunaan analisis regresi linear sederhana adalah untuk menguji hipotesis yang ada dalam penelitian ini yaitu: " pengaruh gaya kepemimpinan Kepala sekolah terhadap kinerja Guru pada SMK Negeri 1 Gowa”. Maka digunakan analisis regresi linear sederhana yang dapat dilihat pada tabel 7

Tabel 7.

Rangkuman Hasil Analisis Regresi Linear Sederhana

\begin{tabular}{lcccccc}
\hline \multicolumn{1}{c}{ Variabel } & R Square & B & F $_{\text {hitung }}$ & Sig. & Thitung & Sig. \\
\hline $\begin{array}{l}\text { Konstanta } \\
\begin{array}{l}\text { Gaya Kepemimpinan } \\
\text { Kepala Sekolah }\end{array}\end{array}$ & 0,078 & 42,050 & & & 8,984 & 0,013 \\
\hline
\end{tabular}

Sumber: Hasil Analisis Statistik Melalui Program SPSS.16

Hasil uji regresi dapat dinyatakan bahwa ada pengaruh positif dan signifikan antara kepemimpinan kepala sekolah terhadap kinerja pada SMK Negeri 1 Gowa. Dengan koefisien determinasinya diperoleh $r^{2}=0,078$ atau 07,80 persen. Yang berarti bahwa pengaruh gaya kepemimpinan kepala sekolah terhadap kinerja guru sebesar 07,80 persen sedangkan sisanya ditentukan oleh faktor lain yang tidak diteliti dalam penelitian ini. Berdasarkan tabel 7 , diketahui perhitungan persamaan regresi linear sederhana diperoleh nilai $\alpha=42,050$ dan $\beta=$ 0,383 sehingga persamaan regresinya adalah $\hat{Y}=42,050+0,383$. Dari hasil perhitungan Uji-F

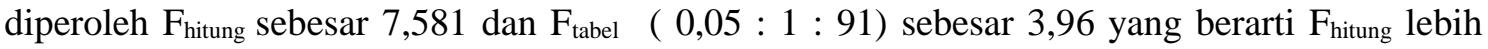
besar daripada $\mathrm{F}_{\text {tabel. }}$. Dikarenakan $\mathrm{F}_{\text {hitung }}>\mathrm{F}_{\text {tabel }}$ maka $\mathrm{H}_{0}$ ditolak dan $\mathrm{H}_{1}$ diterima. Sehingga dapat 


\section{8| Jurnal Office: Jurnal Pemikiran Ilmiah dan Pendidikan Administrasi Perkantoran Vol. 4, No. 2, Juli-Desember 2018, Hal 91-102}

dikatakan bahwa hipotesis yang berbunyi "diduga ada pengaruh gaya kepemimpinana kepala sekolah terhadap kinerja guru di SMK Negeri 1 Gowa" dinyatakan diterima.

\section{Pembahasan}

\section{a. Gaya Kepemimpinan Kepala Sekolah}

Hasil penelitian ini menunjukkan bahwa gaya kepemimpinan kepala sekolah berada dalam kategori sangat baik (tabel 3), ini karena adanya gaya directing (mengarahkan), gaya coaching (melatih), dan gaya supporting (mendukung). Dengan demikian dapat dinyatakan bahwa gaya kepemimpinan kepala sekolah sangat baik. Hal ini dikarenakan kepala sekolah memberikan pengarahan yang baik, kepala sekolah memberikan motivasi terhadap guru, dan kepala sekolah memperhatikan ketersediaan sarana pembelajaran

Kepala sekolah dengan gaya directing lebih banyak memberikan petunjuk yang spesifik dan mengawasi secara ketat proses pembelajaran, sehingga guru yang mempunyai kinerja yang rendah dapat ditingkatkan. Berdasarkan hasil data penelitian pada inidikator gaya directing kepala sekolah SMK Negeri 1 Gowa berada pada kategori baik Dimana kepala sekolah memberikan pengarahan yang baik terhadap guru untuk meningkatkan kinerja guru di SMK Negeri 1 Gowa atau berusaha untuk menggerakkan membuat guru dapat melakukan pekerjaan dengan baik sesuai yang diinginkan oleh kepala sekolah. Dengan demikian kepala sekolah memberi arahan dalam penyelesaian tugas dengan terus menumbuhkan motivasi dan optimis guru SMK Negeri 1 Gowa. Kepala sekolah juga tetap mengawasi penyelesaian tugasnya dengan memperhatikan visi-misi sekolah dan memberikan visi-misi kepada guru agar guru mengetahui dan menjalankan visi-misi sekolah dengan baik. Dalam gaya ini baiknya kepala sekolah lebih memperhatikan lagi penyelesaian tugas yang dilakukan oleh guru agar tidak ada yang tertinggal dan pembelajaran dapat berjalan dengan baik dan dapat mencapai tujuannya.

Kepala sekolah dengan gaya coaching menggunakan directive dan supportive secukupnya artinya pegarahan dan pengawasan tetap dilakukan secara ketat oleh pemimpin. Kepala sekolah selalu memberikan motivasi kepada guru dan setiap pengambilan keputusan meminta saran dari bawahan. Berdasarkan hasil data penelitian pada indikator gaya coachig kepala sekolah SMK Negeri 1 Gowa berada pada kategori baik. Gaya coaching cukup berpengaruh terhadap kinerja guru. Dimana Kepala sekolah SMK Negeri 1 Gowa selalu memperhatikan proses belajar mengajar yang dilakukan oleh guru SMK Negeri 1 Gowa, kepala sekolah juga memberikan motivasi terhadap guru agar guru tetap berpikir inovatif . Kepala sekolah SMK Negeri 1 Gowa lebih berempati kepada setiap guru SMK Negeri 1 Gowa yaitu dengan cara berkomunikasi yang lebih banyak mendegar secara aktif serta bertanya untuk menggali lebih banyak dan kepala sekolah memberikan umpan balik yang positif terhadap guru dalam rangka menggali pencapaian potensi diri. Kepala sekolah harus lebih terbuka lagi dalam pengambilan keputusan agar guru dan kepala sekolah lebih dekat dan menjalani komunikasi yang baik.

Pada gaya supporting, supportive lebih banyak diberikan daripada directive, cocok diterapkan pada guru yang komitmennya kurang baik. Pemimpin dengan gaya ini lebih banyak memberikan fasilitas dan mendukung usaha guru untuk menyelesaikan tugas-tugasnya. 
Berdasarkan hasil data penelitian pada indikator gaya supporting kepala sekolah SMK Negeri 1 Gowa berada pada kategori baik, untuk mendukung pelaksanaan proses belajar mengajar kepala sekolah memperhatikan ketersediaan sarana pembelajaran untuk mendukung pelaksanaan proses pembelajaran agar mencapai tujuan pembelajaran yang diinginkan dan proses pembelajaran berjalan dengan baik. Kepala sekolah SMK Negeri 1 Gowa berusaha agar fasilitas yang disediakkan dapat dimafaatkan oleh guru dengan baik sehingga proses pembelajaran berjalan dengan baik dan mencapai tujuannya. Kepala sekolah baiknya meningkatkan lagi fasilitas sekolah agar guru dan siswa dapat menjalani proses belajar dengan baik dan dapat mecapai tujuan yang diinginkan.

\section{b. Kinerja Guru}

Hasil penelitian menunjukkan bahwa kinerja guru di SMK Negeri 1 Gowa berada pada kategori sangat baik, hal tersebut ditinjau dari indikator sebagai perancang pembelajaran, sebagai pengarah pembelajaran, sebagai pengelola pembelajaran, sebagai konselor, sebagai evaluator, dan sebagai pelaksana kurikulum. Hal ini memberikan indikasi bahwa guru SMK Negeri 1 Gowa memiliki kinerja yang sangat baik, sebagai mana yang dilihat dari data hasil penelitian

Guru dituntut untuk berperan aktif dalam merencanakan pembelajaran dengan memperhatikan komponen dalam sistem pembelajaran.Hasil peneltian ini menunjukkan bahwa tingkat kinerja guru SMK Negeri 1 Gowa berada pada kategori sangat baik. Hal ini ditinjau dari indikator sebagai perancang pembelajaran. Peran guru sebagai perancang pembelajaran dapat dijelaskan bahwa sebelum proses pembelajran guru menyediakan sumber belajar yang akan dibawakan pada proses pembelajaran. Guru SMK Negeri 1 gowa mempersiapkan materi pembelajaran yang relevan dengan tujuan pembelajaran yang sistematis sehingga tujuan pembelajaran tersebut dapat tercapai sesuia yang diinginkan. Guru SMK Negeri 1 Gowa merancang metode pembelajaran dengan baik sesuai dengan situasi dan kondisi peserta didik sehingga peserta didik mampu mencerna dengan baik materi yang disampaikan oleh guru sehingga terjadi timbal balik yang baik dalaam proses pembelajaran.

Salah satu ciri manajemen kelas yang baik adalah adanya kesempatan bagi siswa untuk sedikit demi sedikit mengurangi ketergantungannya pada guru sehingga siswa mampu mengetahui tentang teori belajar dari teori belajar ini dapat mencapai tujuan pembelajaran. Hasil penelitian ini menunjukkan bahwa tingkat kinerja guru SMK Negeri 1 Gowa berada pada kategori sangat baik. Hal ini ditinjau dari indikator sebagai pengelola pembelajaran. Sebagai pengelola pembelajaran, guru SMK Negeri 1 Gowa menggunakan media pembelajaran yang disesuaikan dengan karakteristik peserta didik sehingga mudah dimengerti oleh peserta didik dan proses pembelajaran berjalan dengan baik dan mencapai tujuan yang diinginkan. Guru SMK Negeri 1 Gowa dapat mengendalikan pelaksanaan pengajaran dan menguasai kelas hingga mencapai tujuan pembelajaran yang baik.

Guru senantiasa berusaha menimbulkan, memelihara, dan meningkatkan motivasi peserta didik untuk belajar, dalam hal ini guru mempunyai fungsi sebagai motivator dalam kegiatan pembelajaran. Hasil penelitian menunjukkan bahwa tingkat kinerja guru SMK Negeri 1 Gowa berada pada kategori sangat baik. Hal ini ditinjau dari indikator sebagai pengarah pembelajaran. Peran guru sebagai pengarah pembelajaran, dapat dijelaskan bahwa guru selalu memberikan 


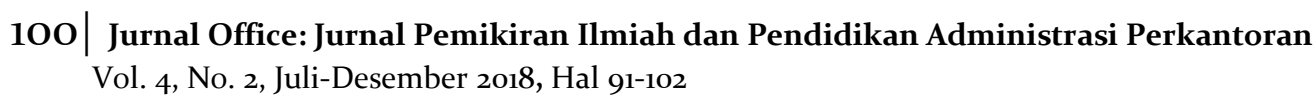

motivasi terhadap peserta didik dalam proses pembelajaran sehingga siswa SMK Negeri 1 Gowa dapat termotivasi mengikuti proses pembelajaran dengan baik. Guru SMK Negeri 1 Gowa selalu memberikan arahan agar peserta didik SMK Negeri 1 Gowa dapat memahami pembelajaran dan dapat mencapai tujuan pembelajaran.yang telah ditetapkan.

Tujuan penilian untuk melihat tingkat keberhasilan, efektivitas dan esensi dalam proses pembelajaran. Guru hendaknya terus-menerus mengikuti hasil belajar yang telah dicapai peserta didik. Hasil penelitian menunjukkan bahwa tingkat kinerja guru SMK Negeri 1 Gowa berada pada kategori sangat baik. Hal ini ditinjau dari indikator sebagai evaluator. Peran guru sebagai evaluator, dapat dijelaskan bahwa setelah memberikan materi pelajaran, guru memberikan evaluasi kepada peserta didik. Setelah peserta didik mengerjakan tugas, guru memberikan umpan balik agar peserta didik dapat termotivasi untuk lebih giat belajar. Guru SMK Negeri 1 Gowa selalu memperhatikan hasil belajar peserta didik SMK Negeri 1 Gowa apakah sudah mencapai tujuan yang diinginkan, dari hasil belajar tersebut guru SMK Negeri 1 Gowa sudah berhasil mencapai tujuan pembelajaran.

Guru diharapkan dapat merespon segala masalah tingkah laku yang terjadi dalam proses pembelajaran.Hasil penelitian menunjukkan bahwa tingkat kinerja guru SMK Negeri 1 Gowa berada pada kategori sangat baik. Hal ini ditinjau dari indikator sebagai konselor. Peran guru sebagai konselor, dapat dijelaskan bahwa guru SMK Negeri 1 Gowa mampu menjalin komunikasi dengan baik terhadap sesama guru, kepala sekolah dan siswa SMK Negeri 1 Gowa. Guru SMK Negeri 1 Gowa sangat merespon baik segala masalah tingkah laku peserta didik yang terjadi dalam proses pembelajaran, guru juga membantu memberikan pemecahan masalah pribadi yang dihadapi peserta didik SMK Negeri 1 Gowa.

Guru adalah orang yang bertanggung jawab dalam upaya mewujudkan segala sesuatu yang telah tertuang dalam kuriikulum resmi. Hasil penelitian menunjukkan bahwa tingkat kinerja guru SMK Negeri 1 Gowa berada pada kategori sangat baik. Hal ini ditinjau dari indikator sebagai pelaksana kurikulum. Peran guru sebagai pelaksana kurikulum, dapat dijelaskan bahwa guru bertanggung jawab dalam upaya mewujudkan segala sesuatu yang telah tertuang dalam suatu kurikulum resmi.Guru SMK Negeri 1 Gowa memberikan masukkan sangat baik berupa saran, ide, dan kritik berdasarkan yang telah dilakukan oleh guru guna menggembangkan suatu kurikulum.

\section{c. Pengaruh Gaya Kepemimpinan Kepala Sekolah terhadap Kinerja Guru}

Berdasarkan hasil pengujian hipotesis Antara variabel gaya kepemimpinan kepala sekolah dengan variabel kinerja Guru SMK Negeri 1 Gowa. Dimana kedua variabel tersebut mempunyai hubungan. Hal ini berarti hipotesis dalam penelitian ini yaitu "diduga terdapat pengaruh Antara gaya kepemimpinan kepala sekolah terhadap kinerja guru pada SMK Negeri 1 Gowa" dapat diterima dengan tingkat pengaruh rendah. Adapun konstribusi variabel gaya kepemimpinan kepala sekolah terhadap kinerja guru dapat dilihat dari nilai koefisien penentu yang diperoleh rendah, sedangkan sisanya dipengaruhi oleh faktor lain yang tidak diteliti dalam penelitian ini. 


\section{SIMPULAN}

Gaya kepemimpinan kepala sekolah SMK Negeri 1 Gowa berada kategori baik, ditinjau dari aspek directing (mengarahkan), gaya coaching (melatih), dan gaya supporting (mendukung). Yang terlaksana dengan baik. Kinerja Guru SMK Negeri 1 Gowa berada pada kategori sangat baik, ditinjau dari aspek sebagai perancang pembelajaran, sebagai pengarah pembelajaran, sebagai pengelola pembelajaran, sebagai konselor, sebagai evaluator, dan sebagai pelaksana kurikulum yang terlaksana dengan sangat baik. 3. Terdapat pengaruh positif yang signifikan pada gaya kepemimpinan kepala sekolah terhadap kinerja guru SMK Negeri 1 Gowa. Hal ini berarti kinerja guru ditentukan oleh gaya kepemimpinan kepala sekolah, sedangkan faktor lain yang tidak diteliti dalam penelitian ini.

\section{DAFTAR PUSTAKA}

Batista-Taran, L. C., Shuck, M. B., Gutierrez, C. C., \& Baralt, S. (2017). The Role of Leadership Style in Employee Engagement. The Role of Leadership Style in Employee. https://doi.org/10.1016/1048-9843(95)90035-7

Chen, J. C., \& Silverthorne, C. (2005). Leadership effectiveness, leadership style and employee readiness. Leadership and Organization Development Journal. https://doi.org/10.1108/01437730510600652

Davis, S., Buskist, W., \& Miller, R. L. (2012). Leadership: Theory and Practice. In 21st Century Psychology: A Reference Handbook. https://doi.org/10.4135/9781412956321.n68

Dobson, S. (1985). Teacher quality. British Journal of In-Service Education. https://doi.org/10.1080/0305763850110306

Drake, W. E. (2008). SCHOOL AND SOCIETY. The Educational Forum. https://doi.org/10.1080/00131726509339652

Elqadri, Z. M., Priyono, P., Suci, R. P., \& Chandra, T. (2015). Effect of Leadership Style, Motivation, and Giving Incentives on the Performance of Employees-PT. Kurnia Wijaya Various Industries. International Education Studies. https://doi.org/10.5539/ies.v8n10p183

Haworth, H. (1983). School. Child and Youth Services. https://doi.org/10.1080/J024v06n03_08

Ismayani, A. I., Niswaty, R., \& Darwis, M. (2015). Peranan Kepala Sekolah Sebagai Leader di SMA Negeri 8 Kabupaten Bulukumba. Jurnal Ad'ministrare: Jurnal Pemikiran Ilmiah Dan Pendidikan Administrasi Perkantoran, 2(2), 101-107.

Nasrullah, M., Rumingan, M., Nasaruddin, N., \& Niswaty, R. (2017). Pengaruh Pengambilan Keputusan Kepala Sekolah terhadap Kinerja Guru di SMK Negeri 1 Makassar. Jurnal Ad'ministrare: Jurnal Pemikiran Ilmiah Dan Pendidikan Administrasi Perkantoran, 4(2), 103-110. 


\section{Jurnal Office: Jurnal Pemikiran Ilmiah dan Pendidikan Administrasi Perkantoran}

Vol. 4, No. 2, Juli-Desember 2018, Hal 91-102

Pencheon, D. (2000). Leadership and motivation. BMJ. https://doi.org/10.1136/bmj.321.7256.S2-7256

Sahandri, M., \& Hamzah, G. (2009). Headmaster and Entrepreneurship Criteria. European Journal of Social Sciences.

Şahenk, S. S. (2010). Characteristics of the headmasters, teachers and students in an effective school. Procedia - Social and Behavioral Sciences. https://doi.org/10.1016/j.sbspro.2010.03.682

Taylor, E. S., \& Tyler, J. H. (2012). The Effect of Evaluation on Teacher Performance. American Economic Review. https://doi.org/10.1257/aer.102.7.3628

Thapa, A., Cohen, J., Guffey, S., \& Higgins-D’Alessandro, A. (2013). A Review of School Climate Research. Review of Educational Research. https://doi.org/10.3102/0034654313483907 